Jurnal Inkofar * Volume 1 No. 1 Juli 2019 * ISSN: 2615-3645 (Print) / 2581-2920 (Online)

Tersedia secara online di: http://www.politeknikmeta.ac.id/meta/ojs/

\title{
ANALISIS KELAYAKAN USAHA GULA MERAH KELAPA (STUDI KASUS: DESA TUMPENG KECAMATAN CANDIPURO KABUPATEN LUMAJANG)
}

\author{
Mustaqim \\ ${ }^{1}$ Program Studi Teknik Industri / Institut Teknologi dan Sains Nahdlatul Ulama Pasuruan / \\ mustaqim.engineer@gmail.com
}

\begin{abstract}
Sugar is one of the important food ingredients which includes nine basic ingredients needed by the community. Coconut sugar UMKM have a great opportunity to improve the regional economy. The research aim to determine the feasibility of coconut sugar business to be carried out. Some things that will be reviewed in the financial feasibility analysis include investment and production cost, cost of good sold, and financial analysis criteria which include BEP, NPV, PBP and BCR. The results of the calculation of the business feasibility analysis of coconut sugar obtained are; will reach BEP by selling 4.853,8 Kg of products. Net Present Value of Rp. 12.952 .434 and Payback Period for 2 years 3 months did not exceed the planned period. Ratio B/C 1,12 whose value is greater than 1 , so that from financial factors, coconut sugar business is feasible.
\end{abstract}

Keywords: coconut sugar, financial analysis, UMKM

\begin{abstract}
ABSTRAK
Gula merupakan salah satu bahan pangan penting yang termasuk sembilan bahan pokok yang diperlukan masyarakat. UMKM gula kelapa berpeluang besar untuk meningkatkan perekonomian daerah. Penelitian ini bertujuan untuk mengetahui kelayakan usaha gula merah kelapa yang akan dijalankan. Beberapa hal yang dikaji dalam analisis kelayakan finansial antara lain biaya investasi dan produksi, harga pokok penjualan, dan kriteria kelayakan usaha yang meliputi BEP, NPV, PBP dan BCR. Hasil perhitungan analisis kelayakan usaha gula merah kelapa yang diperoleh adalah; akan mencapai BEP dengan menjual produk sebanyak 4.853,8 Kg. Net Present Value senilai Rp. 12.952.434 dan Payback Period selama 2 tahun 3 bulan tidak melebihi periode yang direncanakan. Rasio B/C 1,12 yang nilainya lebih besar dari 1, sehingga dari faktor finansial usaha gula merah kelapa layak dijalankan.
\end{abstract}

Kata Kunci: gula kelapa, kelayakan finansial, UMKM

\section{PENDAHULUAN}

Indonesia adalah negara yang subur, memiliki banyak lahan pertanian dan perkebunan sehingga Indonesia dikenal memiliki Sumber Daya Alam (SDA) yang melimpah. Kekayaan sumber daya alam Indonesia khususnya pada sektor perkebunan dapat mendukung ketahanan pangan dengan memaksimalkan SDA yang tersedia. Data BPS Indonesia (2016) menginformasikan luas areal tanaman perkebunan kelapa di Indonesisa cukup potensial seluas 3.533,3 ribu Ha dan merupakan luas areal tanaman perkebunan terluas kedua setelah kelapa sawit.

Kelapa memiliki manfaat yang sangat melimpah dan belum termanfaatkan secara maksimal. Beberapa pemanfaatan kelapa yang dapat digunakan sebagai produk jadi diantaranya sebagai bahan baku kosmetik, karbon aktif, bahan baku obat-obatan dan lain sebagainya. Selain itu, kelapa memiliki cairan yang berasal dari bunga kelapa (mayang) yang disebut Nira dan memiliki kandungan kadar gula tinggi. Produk yang dapat dihasilkan dari nira antara lain gula kelapa, gula semut, biotanol dan pakan lebah (Mugiono et al., 2014).

Gula merupakan salah satu bahan pangan penting yang termasuk sembilan bahan pokok dan harganya langsung ditangani oleh pemerintah (Ariesa and Tinaprilla, 2011). Gula kelapa berperan dalam industri makanan, baik ditingkat industri rumah tangga, kecil, menengah maupun industri besar. Permintaan gula kelapa akan terus meningkat seiring dengan bertambahnya penduduk. Usaha gula kelapa berpeluang besar untuk meningkatkan perekonomian daerah.

Kabupaten Lumajang merupakan daerah yang mayoritas masyarakatnya bermata pencarian sebagai petani dan berkebun. Salah satu sentra perkebunan yang berpotensial di Kabupaten Lumajang adalah 
perkebunan kelapa. Luas tanaman perkebunan kelapa di Kabupaten Lumajang, Jawa Timur seluas 8.129 Ha dengan produksi sebesar 8.136 ton (BPS Lumajang, 2017).

Prastiyo, Muhaimin dan Maulidah dalam analisis nilai tambah nira kelapa pada agroindustri gula merah kelapa pada tahun 2018 dengan hasil pendapatan Rp 560.089 per bulan. Sedangkan penelitian yang dilakukan oleh Praditya (2010) tentang analisis usaha industri gula jawa skala rumah tangga mendapatkan hasil penerimaan sebesar 1,15 kali dari biaya yang telah dikeluarkan.

Saleh (2014) dalam penelitiannya yang berjudul analisis pendapatan usaha pengrajin gula aren di desa Tulo'a Kecamatan Bulango Utara Kabupaten Bone Bolango memberikan hasil R/C Ratio sebesar 2,12 dan menyatakan usaha layak dikembangkan. Penelitian yang dilakukan oleh Ramadani dan Afrida (2017) menyatakan tingkat pendapatan, efisiensi dan BEP pada UMKM gula merah di Desa Sumberingin Kecamatan Sanankulon Kabupaten Blitar berjalan efisien sehingga BEP produksi UMKM gula merah layak untuk dilanjutkan.

Penelitian Dwijatenaya (2017) menyatakan usaha gula aren menguntungkan dengan nilai RC ratio sebesar 1,68 $(1,68>1)$ sedangkan secara teknis tidak efisien dengan nilai 0,999 $(\mathrm{ET}<1)$. Faktor yang berpengaruh terhadap inefisiensi adalah umur dan pendidikan bernilai positif dan pengalaman bernilai negatif. Sedangkan menurut Mugiono et al., (2014) curah hujan yang tinggi menyebabkan bahan baku dan kayu bakar sulit didapat, sehingga memberi dampak penurunan hasil usaha pengolahan gula merah kelapa.

Berdasarkan uraian diatas, akan dilakukan pengkajian analisa kelayakan usaha gula merah kelapa di Desa Tumpeng Kecamatan Candipuro Kabupaten Lumajang Jawa Timur dengan ditinjau dari iklim daerah setempat (musim kemarau dan musim hujan). Penelitian ini bertujuan untuk mengetahui tingkat kelayakan usaha pembuatan gula merah kelapa dengan melihat indikator kelayakan finansial menggunakan metode analisis Net Present Value (NPV), Benefit Cost Ratio (BCR) dan Payback Period (PBP).

\section{METODE PENELITIAN}

Penelitian ini dilaksanakan di Desa Tumpeng Kecamatan Candipuro Kabupaten Lumajang Provinsi Jawa Timur. Penentuan lokasi penelitian secara sengaja berdasarkan atas pertimbangan-pertimbangan tertentu pada saat survey. Penelitian ini melibatkan 7 orang pengelolah gula merah kelapa di desa Tumpeng. Hasil wawancara yang didapat bahwa cara pengelolahan gula merah kelapa masih tradisional yaitu menggunakan kayu bakar. Penelitian ini dilakukan pada bulan November 2018 hingga Januari 2019.

Data yang digunakan dalam penelitian ini adalah data primer dan sekunder. Data primer adalah data yang diperoleh langsung dari obyek yang diteliti dan observasi atau wawancara, sedangkan data sekunder diperoleh dari BPS, studi literatur dari buku, internet dan penelitian sebelumnya.

Analisis data kuantitatif yang digunakan untuk menganalisis kelayakan usaha finansial berdasarkan kriteria kelayakan finansial yaitu metode analisis : BEP, NPV, PBP, dan BCR. Untuk menghitung metode analisis tersebut, ada beberapa hal yang perlu dikaji terlebih dahulu diantaranya; biaya investasi (I), biaya pengeluaran (annual cost), dan biaya produksi serta perhitungan laba/rugi dalam setahun. Berikut adalah rumus kriteria kelayakan finansial adalah (Giatman, 2006):

Net Present Value (NPV) adalah menghitung nilai bersih (netto) pada waktu sekarang (present). Kriteria yang digunakan adalah:

NPV $>0$ artinya investasi akan menguntungkan atau layak (feasible) NPV $<0$ artinya investasi tidak menguntungkan atau tidak layak (unfeasible) $\mathrm{NPV}=0$ artinya usaha tersebut mengembalikan sama besarnya dengan nilai uang yang ditanamkan.

$$
\begin{aligned}
& \mathrm{NPV}=-\mathrm{I}+\mathrm{Ab}(\mathrm{P} / \mathrm{A}, \mathrm{i}, \mathrm{n})+\mathrm{S}(\mathrm{P} / \mathrm{F}, \mathrm{i}, \mathrm{n})-\mathrm{Ac}(\mathrm{P} / \mathrm{A}, \mathrm{i}, \mathrm{n})-\mathrm{Oh}(\mathrm{P} / \mathrm{F}, \mathrm{i}, \mathrm{n}) \\
& \text { Dimana : } \quad \begin{array}{ll}
\mathrm{I} & =\text { Investasi } \\
\mathrm{Ab} & =(\text { Annual benefit }) \text { Uang yang akan diterima ditahun ke-1 } \\
\mathrm{Ac} & =\text { Annual cost } \\
\mathrm{S} & =\text { Salvage } / \text { nilai sisa } \\
\mathrm{Oh} & =\text { Overhoul } \\
\mathrm{n} & =\text { Umur investasi } \\
\mathrm{i} & =\text { Suku bunga }
\end{array}
\end{aligned}
$$


Benefit Cost Ratio (BCR) adalah perbandingan antara benefit bersih dari tahun yang bersangkutan yang telah dipresent valuekan (pembilang / bersifat + ) dengan biaya bersih dalam tahun dimana B-C (penyebut/bersifat -) yang telah dipresent valuekan, yaitu biaya kotor $>$ benefit kotor. Kreteria yang digunakan adalah:

BCR $>1$ investasi layak secara ekonomi (feasible).

$\mathrm{BCR}<1$ investasi tidak layak atau tidak menguntungkan (unfeasible).

$\mathrm{BCR}=\frac{\mathrm{PWB}}{\mathrm{PWC}}$

$\mathrm{PWB}=\mathrm{Ab}(\mathrm{P} / \mathrm{A}, \mathrm{i}, \mathrm{n})+\mathrm{S}(\mathrm{P} / \mathrm{F}, \mathrm{i}, \mathrm{n})$

$\mathrm{PWC}=\mathrm{Ac}(\mathrm{P} / \mathrm{A}, \mathrm{i}, \mathrm{n})$

Payback Period (PBP) pada dasarnya bertujuan untuk mengetahui seberapa lama (periode) investasi akan dikembalikan saat terjadinya pulang pokok (Break Even-Point). Kriteria keputusan sebuah rencana investasi layak secara ekonomi atau tidak layak (unfeasible), jika nilai PBP lebih kecil ( $\mathrm{K}<$ n) dan sebaliknya.

$\mathrm{K}_{(\mathrm{PBP})}=\frac{\mathrm{I}}{\mathrm{Ab}} \mathrm{x}$ tahun

Dimana: $\mathrm{K}=$ jumlah periode pengembalian.

Break Even Point (BEP) adalah suatu titik jumlah produksi atau penjualan yang harus dilakukan supaya biaya yang dikeluarkan dapat tertutupi. Perumusan BEP adalah sebagai berikut (Hidayat et al., 2017):

$\mathrm{BEP}$ unit $=\frac{\mathrm{FC}}{\mathrm{P}-\mathrm{VC}} \quad$ atau $\quad \mathrm{BEP}$ rupiah $=\frac{\mathrm{FC}}{1=\frac{\mathrm{VC}}{\mathrm{P}}}$

Dimana: FC = Biaya tetap

$\mathrm{P} \quad=$ Harga jual per unit

$\mathrm{VC}=$ Biaya variabel per unit

\section{HASIL DAN PEMBAHASAN}

Analisis kelayakan finansial ini dilakukan untuk mengetahui apakah UMKM gula merah kelapa memiliki keuntungan dengan biaya proses produksi yang dikeluarkan. Analisis finansial usaha gula merah kelapa dilakukan dengan asumsi diantaranya: (1) masa usaha diperkirakan selama 5 tahun dengan periode tahunan sesuai dengan nilai ekonomis alat, (2) tingkat suku bunga yang digunakan sebesar 5\%, (3) nilai sisa barang investasi (salvage) sebesar 10\% dari nilai biaya investasi.

\subsection{Analisis Biaya Proses Produksi}

Dalam proses produksi untuk menghasilkan output (produk) tidak terlepas dari biaya. Biaya dalam proses produksi dibagi dua yaitu biaya investasi dan biaya variabel atau biaya pengeluaran. Biaya yang tergolong dalam biaya investasi adalah biaya yang jumlahnya relatif tetap dan tidak terpengaruh oleh volume produksi. Biaya investasi tetap meliputi pembelian mesin dan peralatan yang akan digunakan baik peralatan utama maupun peralatan pendukung (Prasetyo, 2010). Adapun rincian perhitungan biaya investasi untuk usaha gula merah kelapa dapat dilihat pada Tabel 1. dibawah ini.

Tabel 1. Biaya Investasi (I)

\begin{tabular}{|c|c|c|c|c|c|}
\hline \multirow{2}{*}{ No } & \multirow{2}{*}{ Uraian } & \multirow{2}{*}{ Volume } & \multicolumn{2}{|l|}{ Harga (Rp) } & \multirow{2}{*}{$\begin{array}{l}\text { Salvage (S) } \\
\quad \text { (Rp) }\end{array}$} \\
\hline & & & Per satuan & Total & \\
\hline 1 & Sewa tanah & $\mathrm{m}^{2} / \mathrm{thn}$ & & 2.000 .000 & 0 \\
\hline 2 & $\begin{array}{l}\text { Kontruksi bangunan dan } \\
\text { kompor tungku }\end{array}$ & $\mathrm{m}^{2} / \mathrm{thn}$ & & 3.500 .000 & 0 \\
\hline \multicolumn{6}{|c|}{ Peralatan utama dan pendukung } \\
\hline 1 & Wajan & 2 Unit & 1.000 .000 & 2.000 .000 & 200.000 \\
\hline 2 & Timbangan $100 \mathrm{Kg}$ & 1 Unit & 450.000 & 450.000 & 45.000 \\
\hline 3 & Jerigen plastik 30 liter & 6 Unit & 50.000 & 300.000 & 30.000 \\
\hline
\end{tabular}


Jurnal Inkofar * Volume 1 No. 1 Juli 2019 * ISSN: 2615-3645 (Print) / 2581-2920 (Online)

Tersedia secara online di: http://www.politeknikmeta.ac.id/meta/ojs/

\begin{tabular}{lllrrr}
4 & Jerigen plastik 5 liter & 30 Unit & 10.000 & 300.000 & 30.000 \\
5 & Mangkok & 200 Unit & 2.000 & 400.000 & 40.000 \\
6 & Garu kayu & 2 Unit & 15.000 & 30.000 & 3.000 \\
7 & Gayung & 2 Unit & 6.500 & 13.000 & 1.300 \\
8 & Pisau sadap & 2 Unit & 175.000 & 350.000 & 35.000 \\
9 & Kain penyaring & 3 Unit & 5.000 & 5.000 & 500 \\
10 & Motor & 1 Unit & 5.000 .000 & 5.000 .000 & 500.000 \\
& $\quad$ & & 14.348 .000 & 884.800 \\
\hline
\end{tabular}

Berdasarkan Tabel 1. diatas menunjukkan jumlah total biaya investasi yang dikeluarkan untuk merealisasikan usaha gula merah kelapa sebesar Rp. 14.348.000 dengan nilai sisa investasi sebesar Rp. 884.800.

Biaya variabel atau biaya pengeluaran adalah biaya yang dikeluarkan setiap hari ataupun setiap bulan dan sifatnya tidak tetap mengikuti besar kecilnya volume produksi (Utami, 2008). Biaya variabel meliputi sarana produksi (terdiri dari biaya bahan baku air nira dan bahan/peralatan pendukung seperti batu kapur gamping, tali rafia, biaya transportasi, biaya bahan bakar kayu dan biayai tenaga kerja). Biaya bahan bakar memiliki sistem borongan yaitu 1 Pickup habis digunakan selama 15 hari produksi. Berikut adalah rincian perhitungan biaya pengeluaran (annual cost) dapat dilihat pada Tabel 2 dibawah ini.

Tabel 2. Biaya Variabel

\begin{tabular}{|c|c|c|c|c|}
\hline \multirow{2}{*}{ No } & \multirow{2}{*}{ Uraian } & \multirow{2}{*}{ Volume } & \multicolumn{2}{|c|}{ Harga (Rp) } \\
\hline & & & Per satuan & Total per bulan \\
\hline 1 & Gaji tenaga kerja & 2 Orang & & 3.700 .000 \\
\hline 3 & Transportasi & $17 \mathrm{Ltr}$ & 7.650 & 130.050 \\
\hline 4 & Bahan bakar kayu & 2 Pick up & 150.000 & 300.000 \\
\hline 5 & Batu kapur gamping & $5 \mathrm{Kg}$ & 1.400 & 7.000 \\
\hline 6 & Tali rafia & 30 meter & 1.000 & 30.000 \\
\hline 7 & Sewa pohon kelapa & 30 Buah & 10.000 & 300.000 \\
\hline & Jumlah Total & & & 4.467 .050 \\
\hline
\end{tabular}

Berdasarkan pada Tabel 2. menunjukkan bahwa biaya variabel selama 1 bulan sebesar Rp. 4.467.050. Total biaya produksi (biaya investasi dan biaya variabel) yang dibutuhkan untuk menjalankan kegiatan produksi gula merah kelapa selama 1 tahun sebesar Rp. 67.952.600. Diasumsikan sumber dana diperoleh dari dana kredit perbankan dengan bunga pinjaman majemuk 5\%.

Pohon tanaman kelapa yang digunakan sebagai usaha gula merah kelapa diasumsikan sebanyak 30 pohon. Berdasarkan hasil penilaian dari 7 responden UMKM gula merah kelapa di Desa Tumpeng Candipuro Kabupaten Lumajang, bahwa produksi sedapan air nira saat musim panas mencapai ratarata 5 Liter per tanaman kelapa. Sedangkan pada saat musim hujan, produksi sedapan air nira mencapai rata-rata 2,5 Liter per tanaman kelapa. Setiap 5 Liter air nira menghasilkan $1 \mathrm{Kg}$ gula merah kelapa.

Berdasarkan uraian diatas bahwa produksi gula merah kelapa per 30 pohon saat musim panas mencapai $5.400 \mathrm{Kg}$, sedangkan saat musim hujan mencapai $2.700 \mathrm{Kg}$.

\subsection{Analisa Nilai Pendapatan}

Pendapatan merupakan total nilai dari penjualan produk dalam jangka waktu tertentu ditambahkan dengan biaya proses produksi. Berdasarkan hasil observasi dan analisa perhitungan diperoleh bahwa produksi gula merah mampu memproduksi $30 \mathrm{Kg}$ per hari saat musim panas dan $15 \mathrm{Kg}$ per hari saat musim dingin. Adapun produk gula merah kelapa dijual dengan harga Rp. 14.000 per Kg dan diasumsikan harga penjualan konstan selama periode usaha ini. Harga jual tersebut dibawah dari harga rata-rata pasar yang ada. 
Adapun rincian perhitungan pendapatan yang diterima oleh UMKM gula merah kelapa dapat dilihat pada Tabel 3 berikut:

Tabel 3. Rincian pendapatan usaha gula merah kelapa

\begin{tabular}{clrc}
\hline No & \multicolumn{1}{c}{ Uraian } & \multicolumn{2}{c}{ Nilai (Rp) } \\
\hline 1 & Pengeluaran per bulan (30 hari) & & 4.567 .050 \\
& Pengeluaran per tahun (Annual Cost) (12 bulan) & & 54.804 .600 \\
& $\quad$ Penjualan Gula Merah Kelapa & Musim kemarau & Musim hujan \\
2 & Harga Gula Merah Kelapa per Kg & 14.000 & 14.000 \\
& Penjualan per hari & 420.000 & 210.000 \\
& Penjualan per bulan (30 hari) & 12.600 .000 & 6.300 .000 \\
& Penjualan per 6 bulan & 75.600 .000 & 37.800 .000 \\
& Penjualan pertahun & & 113.400 .000 \\
& $\quad$ Laba (Annual Benefit) & & \\
3 & Laba per bulan (30 hari) & & 8.032 .950 \\
& Laba per tahun (12 bulan) & 58.595 .400 \\
\hline
\end{tabular}

Berdasarkan hasil perhitungan pada Tabel 3 menunjukkan bahwa pendapatan usaha gula merah kelapa menghasilkan keuntungan sebesar Rp. 58.595.400 per tahun. Hasil tersebut belum dapat menutupi kembali biaya proses produksi dengan suku bunga 5\%, oleh karena itu untuk mengetahui keuntungan usaha dan titik impas atau layak tidaknya usaha ini maka dilakukan analisis kreteria kelayakan finansial.

\subsection{Analisa Nilai Pendapatan}

a. $\quad$ Net Present Value (NPV)

Perhitungan NPV menggunakan rumus 1 dengan besaran discount rate adalah $5 \%$ dan overhoul sebesar Rp. 250.000. Hasil perhitungan yang diperoleh bahwa nilai NPV adalah Rp. 12.952.434 (positif) artinya bahwa investasi yang dilakukan hingga 5 tahun mendatang akan diperoleh manfaat bersih sebesar Rp. 12.952.434 sehingga dapat dinyatakan bahwa usaha ini menguntungkan dan layak untuk dijalankan secara ekonomi.

b. $\quad$ Benefit Cost Ratio (BCR)

Berdasarkan hasil perhitungan yang diperoleh bahwa nilai Net B/C Ratio sebesar $1,12>1$ (net benefit bersifat positif) artinya bahwa setiap pengeluaran Rp. 100 akan mendapat benefit sebesar Rp. 112.

\section{c. Payback Period (PBP)}

Hasil perhitungan yang diperoleh bahwa Payback Period (PBP) bernilai 2,32 $<\mathrm{n}=5$ (lebih kecil dari umur investasi 5 tahun), maka dapat dinyatakan periode pengembalian investasi usaha gula merah kelapa selama 2 tahun 3 bulan.

d. Break Even Point (BEP)

BEP adalah suatu kondisi dimana usaha tidak mendapat keuntungan dan kerugian. Perhitungan Break Even Point menggunakan rumus 4 dan 5, dimana dari hasil perhitungan diperoleh bahwa BEP produk $\begin{array}{llllll}\text { yaitu } & 4.853,8 & \mathrm{Kg} & \text { dan } & \mathrm{BEP} & \text { harga }\end{array}$ Rp. 8.389,2. Sementara nilai produksi gula merah kelapa adalah $8.100 \mathrm{Kg} /$ tahun dengan harga jual Rp. $14.000 / \mathrm{Kg}$. Uraian diatas dapat disimpulkan bahwa jumlah tersebut lebih dasar dari BEP produk dan BEP harga maka usaha ini dikatakan layak dijalankan.

\subsection{Analisa Aspek Non Finansial}

Dalam pengaruh faktor finansial, industri pembuatan gula merah mendorong terciptanya lapangan kerja sehingga menyebabkan peningkatan pendapatan masyarakat. Selain pengaruh faktor finansial, pengaruh faktor sosial memberikan pengaruh terhadap kehidupan sosial masyarakat, terutama dalam bidang pendidikan. Munculnya industri gula merah membawa pengaruh perubahan adanya kemajuan, baik kemajuan mental, fisik maupun perekonomian. 
Jurnal Inkofar * Volume 1 No. 1 Juli 2019 * ISSN: 2615-3645 (Print) / 2581-2920 (Online)

Tersedia secara online di: http://www.politeknikmeta.ac.id/meta/ojs/

\section{KESIMPULAN}

Berdasarkan hasil penelitian dan perhitungan analisis finansial UMKM gula merah kelapa diperoleh hasil NPV lebih dari 0 yaitu Rp. 12.952 .434 (positif), BCR sebesar 1,12 lebih besar dari 1 dan PBP selama 2 tahun 3 bulan tidak melebihi periode usaha yang direncanakan. Nilai BEP harga sebesar Rp. 8.389,2 dan BEP unit adalah 4.853,8 Kg. Hasil sisi finansial UMKM gula merah kelapa dalam dua musim (kemarau dan hujan) dapat disimpulkan bahwa usaha menguntungkan dan layak untuk dijalankan.

\section{DAFTAR PUSTAKA}

Ariesa, F. N. and Tinaprilla, N. (2011) 'Analisa Kelayakan Restrukturisasi Mesin Pabrik Gula Kremboong, Kabupaten Sidoarjo, Jawa Timur', Agribusiness Forum, 1(1), p. 58.

BPS Indonesia (2016) Statistical Yearbook of Indonesia 2016.

BPS Kabupaten Lumajang (1385) Lumajang Regency in Figures 2017.

Dwijatenaya, I. B. M. A. (2017) 'Benefits and Efficiency of Palm Sugar Business', Jurnal 'Gerbang Etam’ Balibanda Kab. Kukar, 11(1), pp. 45-53.

Giatman, M. (2006) EKONOMI TEKNIK. 1st edn. Edited by A. Aliudin. Jakarta: PT RajaGrafindo Persada.

Hidayat, A. F. et al. (2017) 'Analisa Kelayakan Finansial Usaha Agroindustri Abon Ikan Di Tanjung Karang, Kota Mataram', Jurnal Ilmiah Rekayasa Pertanian dan Biosistem, 5(2), pp. 452-461. doi: $10.1017 /$ S1537592717003139.

Mugiono, Marwanti, S. and Awami, S. N. (2014) 'Analisis Pendapatan Usaha Gula Merah Kelapa (Studi Kasus Di Desa Medono Kecamatan Kaliwiro Kabupaten Wonosobo)', Jurnal Ilmu-ilmu Pertanian, 10(2), pp. 22-31.

Praditya, M. (2010) Analisis Usaha Industri Gula Jawa Skala Rumah Tangga di Kabupaten Wonogiri. Universitas Sebelas Maret.

Prasetyo, W. (2010) ANALISIS BREAK EVEN POINT ( BEP ) PADA INDUSTRI PENGOLAHAN TEBU DI PABRIK GULA ( $P G$ ) MOJO KABUPATEN SRAGEN. Universitas Sebelas Maret.

Prastiyo, D. B., Muhaimin, A. W. and Maulidah, S. (2018) 'Analisis Nilai Tambah Nira Kelapa Pada Agroindustri Gula Merah Kelapa (Kasus Pada Agroindustri Gula Merah Desa Karangrejo Kecamatan Garum, Blitar)', Journal Ekonomi Pertanian dan Agribisnis (JEPA), 2(1), pp. 41-51.

Ramadani, A. and BR, A. (2017) 'Analisis Efisiensi Usaha Mikro Kecil Menengah Gula Merah di Desa Sumberingin Kecamatan Sanankulon Kabupaten Blitar', 1, pp. 44-60.

Saleh, Y. (2014) ‘Analisis Pendapatan Usaha Pengrajin Gula Aren Di Desa Tulo'a Kecamatan Bulango Utara Kabupaten Bone Bolango', Jurnal Perspektif Pembiayaan dan Pembangunan Daerah, 1(4), pp. 219-224.

Utami, M. F. (2008) Studi pengembangan usaha gula merah tebu di kabupaten rembang. Institut Pertanian Bogor. 